\title{
MODEL KOOPERATIFTIPE STAD DALAM PEMBELAJARAN MENULIS FABEL DI KELAS VII SMP NEGERI 2 SERIRIT
}

\author{
Ni Putu Eka Mariani ${ }^{1}$, I Wayan Wendra ${ }^{2}$, I Nyoman Yasa ${ }^{3}$ \\ Prodi Pendidikan Bahasa Indonesia, Jurusan Bahasa Sastra Indonesia dan \\ Daerah, Fakultas Bahasa dan Seni, Universitas Pendidikan Ganesha \\ Singaraja, Indonesia \\ e-mail :ekamariani10@gmail.com ${ }^{1}$,wayanwendra@yahoo.com ${ }^{2}$, \\ keswa.kanaya@yahoo.com ${ }^{3}$
}

\begin{abstract}
ABSTRAK
Penelitian ini bertujuan untuk mendeskripsikan (1) pelaksanaan pembelajaran menulis teks fabel menggunakan Model Kooperatif STAD (2) hasil belajar siswa setelah menggunakan model pembelajaran kooperatif tipe STAD (3)mengetahui respons siswa terhadap pelaksanaan pembelajaran menggunakan Model Kooperatiftipe STAD. Penelitian ini menggunakan rancangan penelitian deskriptif kualitatif dan deskriptif kuantitatif dengan subjek guru bahasa Indonesia, siswa kelas VIIdi SMPN 2 Seririt. Objek penelitian ini adalahpelaksanaan,hasil dan respons siswa terhadap Model KooperatifSTAD. Data dikumpulkan dengan metode observasi, dokumentasi dan angket. Analisis data dilakukan dengan cara reduksi data, penyajian data, dan, penyimpulan. Adapun hasil penelitian ialah (1)pelaksanaan pembelajaran model STAD menggunakan 16 langkah, sesuai dengan langkah model tipe STAD (2) hasil belajar siswa mendapat hasil yang baik $(83,55)$ dan (3) kelas VII merespons sangat positifterhadap model pembelajaran kooperatif tipe STAD.
\end{abstract}

Kata Kunci: Model Pembelajaran Kooperatif STAD.

\begin{abstract}
This study aimed at describing (1) the implementation of writing about fable text using STAD cooperative model (2) students' achievement after using STAD cooperative learning model type (3) the responses of students toward the implementation of learning that uses STAD type cooperative model. This study used qualitative and quantitative research, in which the subjects of this study were Indonesian Language teacher and seven grade students of SMPN 2 Seririt. The objects of this study were the implantation, result, and response of the students toward STAD cooperative model. The data were collected through observation, documentation, and questionnaire. The data analysis was done by three steps, namely: data reduction, data presentation, and conclusion. The result of this study were (1) the implementation of STAD learning model using 16 steps,according to the STAD type model step (2) the students' achievement get a good result $(83,55)$ and $(3)$ seven grade students respond very positive toward STAD cooperative learning model type.

Keywords :STAD cooperative learning model.
\end{abstract}

\section{PENDAHULUAN}

MatapelajaranBahasalndonesia

merupakan salah mata pelajaran

penentu kelulusan siswa pada pemerolehan empat ketrampilan berbahasa. Keempat keterampilan tersebut berkaitan dan saling mendukung dalam proses belajar 
mengajar di kelas. Keempat aspek keterampilan tersebut adalah keterampilan menyimak, berbicara, membaca, dan menulis. Keempat keterampilan berbahasa disajikan secara terpadu namun dimungkinkan untuk memberikan penekanan pada salah satu keterampilan,misalnya ketrampilan menulis. Keterampilan menulis sangat penting dikuasai oleh siswa dalam pengajaran Bahasa Indonesia di sekolah.Dalam Akhadiah (Putra,2013:2)menyatakan menulis memiliki beberapakeuntungan salah satunya adalah dengan menulis, dapat lebih mengenali kemampuan dan potensi diri. (Radhika,2014:4) menyatakan "dalam Kurikulum 2013 ini peserta didik diwajibkan menguasai keterampilan berbahasa termasuk keterampilan menulis" salah satu fokus siswa dalam Kurikulum 2013 adalah menulis cerita moral/fabel.

Pembelajaran Bahasa Indonesia telah diatur dalam kurikulum sekolah yaitu Kurikulum 2013. Salah satu keterampilan menulis yang harus dikuasai adalah menulis teks fabel. Menurut Fang (2011:4-5) Cerita fabel merupakan sebuah cerita mengenai kehidupan binatang yang berprilaku menyerupai manusia. Cerita fabel tergolong kedalam jenis cerita fiksi karenasuatu cerita yang bukan berasal dari kehidupan yang nyata atau disebut juga dengan cerita fiktif. Cerita fabel disebut juga dengan cerita moral, hal tersebut dikarenakan pesan yang terdapat didalam cerita fabel sangat erat kaitannyadengan moral kehidupan. Dalam teks fabel pembaca langsung bisa menemukan amanat atau nilai moral pada bagian akhir atau kesimpulan cerita. Secara umum, teks fabel memiliki struktur yang terdiri atas orientasi, komplikasi, resolusi, dan koda.

Dalam kurikulum SMP/MTs kelas VII, pengajaran keterampilan menulis seperti menulis teks fabel di ajarkan pada kelas VII semester genap (Nasution, 2018). Pembelajaran cerita fabel dapat menggali potensi siswa untuk menulis sehingga cukup penting untuk dilaksanakan.

Dalam pelaksanaan pembelajaran secara umum, diperlukan kerja sama antara siswa dan guru supaya tujuan pembelajaran dapat tercapai. Kriteria ketercapainya tujuan pembelajaran adalah adanya peningkatan hasil belajar siswa setelah mengikuti pembelajaran. Pembelajaran yang selama ini dilakukan oleh kebanyakan guru cenderung masih menggunakan pembelajaran yang terbilang konvensional seperti metode ceramah, sehingga siswa sering bosan dan malas untuk mengikuti pembelajaran. Sehubungan dengan hal itu, maka diperlukan model dan media pembelajaran yang tepat untuk menunjang kegiatan belajar mengajar sekaligus untuk mengurangi kesulitan yang dialami siswa saat menerima pembelajaran.

Model yang relevan diperlukan meningkatkan, dan menumbuhkembangkan kemampuan berimajinasi peserta didik. Salah satu cara memperbaiki rendahnya minat menulis peserta didik adalah dengan cara mengubah model pembelajaran yang biasa digunakan dengan model pembelajaran yang lebih mendukung aktivitas peserta didik dalam memahami suatu materi dan lebih menekankan peserta didik berperan aktif dalam pembelajaran sehingga dapat meningkatkan minat dan motivasi siswa dalam belajar. Muharom (2014) menyatakan bahwa model pembelajaran yang efektif dan diperkirakan dapat meningkatkan minat belajar peserta didik adalah model pembelajaran kooperatif, 
sebab dalam pembelajaran kooperatif peserta didik ditekankan untuk lebih aktif. Dalam prosesnya peserta didik dituntut untuk bekerja sama dengan teman sekelompoknya untuk memahami sesuatu permasalahan sehingga proses belajar dan komunikasi lebih baik dan lebih mudah untuk dijelaskan.

Berdasarkan hasil wawancara dengan guru mata pelajaran Bahasa Indonesia yakni Putu Ardana S.Pd yang mengampu pelajaran di kelas VII menyatakan "untuk mengurangi kesulitan dalam pembelajaran menulis cerita fabel yang dialami siswa, maka perlu digunakan model atau media yang efektif dalam pembelajaran bahasa Indonesia". Model Student Teams Achievement Division (STAD) adalah model pembelajaran yang sering digunakan oleh guru bahasa Indonesia maupun guru pengampu mata pelajaran yang lain, karena model pembelajaran STAD dirasa cocok untuk membantu megatasi kesulitan yang di alami oleh siswa yang ada di SMPN 2 Seririt. Model pembelajaran kooperatif STAD ini berkali-kali digunakan oleh guru bahkan sampai saat ini. Model ini digunakan karena mengalami peningkatan bagus untuk memotivasi siswa. Pada saat ini guru bahasa Indonesia masih terus menggunakan model pembelajaran kooperatif tipe STAD.

Model ini dipertahankan untuk membantu meningkatkan motivasil siswa dalam belajar. Dengan keberhasilan model ini, maka peneliti ingin mendeskripsikan bagaimana pelaksanaan,hasil dan respons siswa terhadap pembelajaran menggunakan Model Kooperatiftipe STAD.

Pembelajaran kooperatif tipe STAD merupakan suatu model pembelajaran yang melatih siswa dalam menjalin kerjasama dalam satu kelompok kecil dan saling membantu dalam memecahkan masalah, sehingga dalam penguasaan materi pelajaran memperoleh pemahaman yang sama. Belajar kooperatif merupakan strategi belajar dimana siswa belajar dalam kelompok kecil yang memiliki tingkat kemampuan yang berbeda. Di dalam pembelajaran kooperatif siswa belajar bersama dalam kelompok yang terdiri 4-6 siswa. Setiap kelompok mempunyai anggapan bahwa dalam menyelesaikan tugas secara kelompok setiap orang saling bekerja dan membantu untuk memahami suatu bahan pelajaran. Lamba (2006:124) Belajar kooperatif adalah sebagai kumpulan strategi mengajar yang digunakan siswa untuk membantu satu dengan yang lain dalam suatu kelompok untuk mempelajari sesuatu.

Penggunaan

model

pembelajaran STAD mendapatkan respons yang baik dari kalangan siswa hal tersebut dikarenakan model pembelajaran STAD jika diterapkan di dalam kelas sangat menarik perhatian siswa apalagi jika diselingi dengan media pembelajaran, tentu saja hal tersebut membuat siswa sangat menikmati proses pembelajaran.

Dengan menggunakan model pempelajaran STAD, maka siswa akan termotivasi dan mampu mengembangkan imajinasi yang dimiliki dari cerita yang sudah disiapkan sebelumnya oleh guru.Beberapa penelitian sejenis juga menyebutkan, salah satunya penelitian yang dilakukan oleh Husna Rahmayunit (2016) dengan judul "Keefektifan model student teams achievement Division dengan media vidio clip dalam pembelajaran menulis kelas x SMA". Dalam penelitian yang dilakukan siswa menjadi lebih termotivasi dalam 
belajar kerena menggunakan model kooperatif tipe STAD dan ditambah dengan menggunakan media pembelajaran vidio clip, hal tersebut membuat siswa merasa senang mengikuti proses pembelajaran.

Menurut Davidson (dalam Tapan, 2011) menyatakan kelebihan model Pembelajaran kooperatif tipe Student Teams Achievement Division (STAD) yaitu: meningkatkan kecakapan individu, meningkatkan kecakapan kelompok, meningkatkan komitmen dan percaya diri, menghilangkan prasangka terhadap teman sebaya dan memahami perbedaan, tidak bersifat kompetitif, tidak memiliki rasa dendam dan mampu membina hubungan yang hangat, serta meningkatkan motivasi belajar dan rasa toleransi serta saling membantu dan mendukung dalam memecahkan masalah.

Model pembelajaran kooperatif tipe Student Team Achievement Division (STAD) ini diharapkan dapat meningkatkan keaktifan seluruh siswa dalam kelompoknya dan dalam mengikuti proses pembelajaran di kelas agar dapat meghasilkan hasil belajar yang lebih memuaskan dari sebelumya.

Berdasarkan hasil observasi awal peneliti di SMP Negeri 2 Seririt dapat dianalisis bahwa Model Kooperatiftipe STAD menjadi model yang paling sering digunakan karena mendapat hasil yang baik dalam proses pembelajaran. Maka penelitian ini mengkaji mengenai bagaimana pelaksanaan pembelajaran teks fabel menggunakan model kooperatif STAD, kemudian bagaimana hasil pembelajaran setelah mengunakan model STAD dan respons siswa terhadap pelaksanaan pembelajaran menggunakan model STAD.
Tujuan dari penelitian ini adalah (1) Untuk mendeskripsikan pelaksanaan pembelajaran dengan menggunakan model pembelajaran kooperatif STAD materi menulis fabel,(2) Untuk mendeskripsikan hasil belajar siswa setelah menggunakan model pembelajaran kooperatif STAD materi menulis fabel dan (3) Untuk mendeskripsikan respons siswa terhadap pelaksanaan model pembelajaran kooperatif STAD materi menulis fabel.

Manfaat penelitian ini dapat memberikandua manfaat, yaitu manfaat teoretis dan manfaat praktis. Secara teoretis, penelitian ini dapat dijadikan bahan kajian yang berguna dalam perkembangan ilmu pendidikan, khususnya dalam model pembelajaran menulis cerita fabel. Manfaat praktis penelitian ini berupa sumbangan bagi semua kalangan yang terlibat dalam pendidikan seperti bagi siswa dapat memberikan pengetahuan dan pengalaman baru serta memudahkan siswa dalam pembelajaran menulis fabel dan tentunya dapat melatih kekompakan dalam tim sehingga akan membuat siswa semakin termotivasi meningkatkan hasil belajar kemudian bagi gurudapat dijadikan referensi bagi guru bahasa Indonesia dalam upaya meningkatkan hasil belajar siswa dan dapat mengatasi kesulitan siswa dalam pembelajaran menulis fabel dan bagi sekolah dapat digunakan untuk meningkatkan kualitas pembelajaran di SMPN 2 Seririt dan dapat menghasilkan lebih banyaksiswa yang berkualitas.

\section{METODE PENELITIAN}

Metode penelitian yang
digunakan dalam penelitian mencakup (1) rancangan penelitian, (2)subjek dan objek penelitian, (3) metode pengumpulan data, (5) instrumen penelitian, dan (6) teknik 
analisis data. Rancangan penelitian yang digunakan dalam penelitian ini adalah rancangan deskriptif kualitatif dan deskriptif kuantitatif.Subjek dalam penelitian ini adalah guru bahasa Indonesia kelas VII, siswa kelas VII SMP Negeri 2 Seririt. Objek dalam penelitian

ini adalahpelaksanaan, hasil dan respons siswa terhadap model pembelajaran kooperatif tipe STAD.

Teknik analisis deskriptif kualitatif adalah suatu teknik menganalisis data dengan cara menginterpretasikan data yang diperoleh dengan kata-kata. Kemudian analisis deskriptif kuantitatif merupakan analisis untuk data yang berupa angka.

Untuk permasalahan yang pertama yakni pelaksanaan pembelajaran bahasa Indonesia, menulis cerita fabel menggunakan Model Pembelajaran Kooperatif tipe STADmenggunakan metode observasi kemudian intrumennya berupa lembar observasi dan analisis data merupakan deskriptif kualitatif. Kemudian permasalahan yang kedua merupakan hasil pembelajaran bahasa indonesia, menulis cerita fabel menggunakan model pembelajaran kooperatif tipe $S T A D$, metode yang digunakan adalah metode dokumentasi, untuk intrumen digunakan berupa hasil penilaian guru dan analisis data yang digunakan merupakan deskriptif kualitatif. Untuk permasalahan yang ketiga yakni respons siswa terhadap pelaksanaan pembelajaran teks fabel menggunakan model kooperatif STAD, metode yang digunakan adalah metode angket kemudian instrument yang digunakan adalah instrumen angket. Analisis data adalah analisis deskriptif kuantitatif.

HASIL DAN PEMBAHASAN
Hasil penelitian ini mencakup (1) pelaksanaan pembelajaran Model KooperatifSTAD dalam menulis fabel di kelas VII SMPN 2 Seririt, menggunakan $16 \quad$ langkah pelaksanaan sesuai dengan model kooperatif STAD (2) hasil belajar siswa setelah menggunakan model pembelajaran kooperatif STAD untuk menulis fabel di kelas VII SMPN 2 Seririt, mendapat hasil yang baik $(83,55)$ dan (3) respons siswa terhadap pelaksanaan model pembelajaran kooperatif STAD dalam menulis fabel di kelas VII SMPN 2 Seririt mendapat hasil sangat positif terhadap pelaksanaan pembelajaran mengunakan model kooperatif tipe STAD.

Pelaksanaan kegiatan pembelajaran dilaksanakan sesuai dengan rencana pelaksanaan pembelajaran yang sudah dirancang yaitu Model Pembelajaran Kooperatif tipe STADuntuk materi teks fabel. Pelaksanaan pembelajaran meliputi pemberian salam dan mengecek kehadiran siswa kemudian kegiatan inti membagi siswa menjadi beberapa kelompok yang terdiri dari 4-6 siswa dan kegiatan akhir yakni mengakhiri proses pembelajaran. Untuk langkah-langkah yang digunakan dalam pembelajaran terdapat enam belas langkah kemudian dari keenam belas langkah tersebut terdapat enam langkah utama yang menjadi ciri khas dari Model Pembelajaran Kooperatif tipe STAD.

Hal tersebut $\begin{array}{r}\text { didukung } \\ \text { dengan plavin }\end{array}$
$(2010: 45)$ bahwa ada 6 langkah
utama di dalam model
pembelajaran STAD, yakni (1)
Penyampaian tujuan dan motivasi, an dari guru,(4)kegiatan belajar dalam tim,(5)kuis atau evaluasi dan 
(6)penghargaan prestasi tim. Selain pendapat dari Slavin terdapat juga penelitian yang menggunakan 16 langkah pelaksanaan pembelajaran model kooperatif STAD oleh Kumarawati (2015) dengan judul "Penerapan metode pembelajaran kooperatif student teams achievement division (STAD) untuk meningkatkan kemampuan menulis teks laporan hasil observasi siswa kelas x mia 1 SMAN 1 Mendoyo" yang juga menunjukkan bahwa dalam penelitiannya menggunakan 16 langkah pelaksanaan pembelajaran menggunakan model kooperatif STAD dimulai dari pemberian salam hingga mengakhiri pembelajaran.

Hasil pembelajaran yang didapatkan oleh siswa kelas VII A dan $B$, nilai tertinggi yang diperoleh adalah 100 yang dikategorikan sangat baik dan untuk skor terendah yang diproleh siswa adalah 75 yang masuk dalam kategori baik. Hasil belajar setelah menggunakan Model Kooperatif tipe STAD yang dilakukan di kelas VII A dan B di SMPN 2 Seririt mendapatkan hasil yang memuaskan dengan nilai rata-rata 83,55 yang dikategorikan baik.

Mendapatkan hasil yang baik tentunya tidak terlepas dari pelaksanaan pembelajaran yang menggunakan Model Kooperatif STAD serta kelebihan yang dimiliki oleh model kooperatif STAD yang membuat siswa mendapatkan hasil yang baik dalam pembelajaran.

\section{Adapun kelebihan dari}

model kooperatif STAD yang menjadikan model ini disenangi oleh siswa saat proses pembelajaran. Menurut Kurniasih (2015:22) inilah beberapa kelebihan model STAD yaitu; dalam kelompok siswa di tuntut aktif sehingga dengan model ini, siswa dengan sendirinya akan percaya diri dan meningkatkan kecakapan individualnya, mengajarkan saling menghargai orang lain, dengan kelompok yang ada siswa diajarkan untuk membangun komitmen dalam mengembangkan kelompoknya. Model Pembelajaran Kooperatif tipe STAD membantu menumbuhkan kerja sama yang baik antar siswa dalam menghadapi suatu permasalahan. Hal ini juga didukung dengan pernyataan Davidson (dalam Tapan, 2011) menyatakan kelebihan model Pembelajaran kooperatif tipe Student Teams Achievement Division (STAD) yaitu: meningkatkan kecakapan individu, meningkatkan kecakapan kelompok, meningkatkan komitmen dan percaya diri, menghilangkan prasangka terhadap teman sebaya dan memahami perbedaan, tidak bersifat kompetitif, tidak memiliki rasa dendam dan mampu membina hubungan yang hangat, serta meningkatkan motivasi belajar dan rasa toleransi serta saling membantu dan mendukung dalam memecahkan masalah.

Model pembelajaran
kooperatif tipe Student Team Achievement Division (STAD) ini dapat meningkatkan keaktifan seluruh siswa dalam kelompoknya dan dalam mengikuti proses pembelajaran di kelas agar dapat meghasilkan hasil belajar yang lebih memuaskan dari sebelumya. Sebelum penelitian ini direncankan, ditemukan hasil penelitian yang juga meneliti mengenai pemakaian Model Kooperatif STADyang dilakukan oleh dilakukan oleh Mia, dkk (2016) dengan judul "model pembelajaran student teams achiavement Division untuk meningkatkan keaktifan dan keterampilan menulis puisi siswa sekolah menengah pertama". Hasil penelitian dan pembahasannya adalah mengenai keaktifan dalam proses pembelajaran. 
Respons siswa menunjukkan bahwa pelaksanaan pembelajaran menggunakan Model Kooperatif STADpada mata pelajaran bahasa Indonesia menulis teks fabel sangat positif. Siswa memberikan respons sangat positif terhadap pembelajaran menulis teks fabel menggunakan model pembelajaran kooperatif STAD. Hal tersebut dapat diketahui dari rata-rata respons siswa. Berdasarkan hasil penelitian dengan angket yang disebarkan kepada siswa yakni dari 60 siswa terdapat53siswa menyatakan sangat positif dan 7siswa menyatakan positif. Dengan demikian, data secara keseluruhan menyatakan sangat positif dengan rata-rata skor 33,05.

Respons sangat positif yang diberikan siswa menunjukkan bahwa siswa menyetujui dan menerima pelaksanaan pembelajaran menggunakan Model Kooperatif STAD pada mata pelajaran bahasa Indonesia menulis fabel dengan sangat baik. Hal tersebut sejalan dengan pendapat Harvey dan Smith (dalam Ahmadi, 1999) bahwa respons positif adalah sebuah respons, tindakan, atau sikap yang menunjukkanatau memperlihatkan, menerima, mengakui, menyetujui, serta melaksanakan norma-norma yang berlaku dimana individu itu berada. $\mathrm{Hal}$ ini didukung oleh pernyataan Ellis (2008:21) yang memaparkan bahwa pembelajaran berbasis kelompok merupakan ajang kesempatan berdiskusi yang bagus bagi siswa, membuat siswa dapat menemukan langsung permasalahan yang akan dipercahkan bersama. Memberi siswa kesenangan dalam pembelajaran dan dapat dijadikan strategi mengajar yang efektif.

Terdapat beberapa faktor yangmenjadikan model ini mampu menciptakan suasana pembelajaran yang menyenangkan bagi siswa. Faktor tersebut adalah karakter STAD sebagai model pembelajaran yang menuntut kerjasama, pembelajaran berpusat pada siswa (Student Centered), dan adanya penghargaan bagi tim terbaik. Model STAD sangat menekankan pada kerjasama dalam kelompok belajar. Hal ini akan menuntut siswa untuk saling membantu, memberi motivasi, dan saling percaya satu sama lain. Pembelajaran yang menekankan pada kerjasama akan memberi kesempatan kepada siswa untuk belajar bekerjasama, berbagipendapat, pengetahuan, pengalaman, mendengarkan pendapat orang lain, saling memotivasi dan aktif dalam kegiatan pembelajaran.

Selain faktor dari karakteristik model STAD terdapat juga kelebihan dari model ini yang mampu membuat siswa merasa senang dalam pelaksanaan pembelajaraan. Kelebihan Model Pembelajaran Kooperatif Tipe STAD yaitu siswa lebih mudah memahami materi pelajaran karena mereka sudah terbiasa untuk belajar kooperatif dalam arti bekerja secara kelompok untuk memecahkan setiap persoalan dan Model Pembelajaran Kooperatif tipe STAD dapat menciptakan rasa percaya diri pada diri siswa, suasana rukun, saling berbagi dan bertanggung jawab (Hartono,2009:112).

Jadi respons pelaksanaan pembelajaran menggunakan model kooperatif STAD dapat membuat siswa menjadi lebih termotivasi dan tertarik mengikuti pembelajaran menulis teks fabel sehingga mendapatkan hasil yang sangat positif, maka dapat disimpulkan bahwa model pembelajaran kooperatif STAD sangat tepat 
diterapkan dalam proses pembelajaran di SMPN 2 Seririt.

Pada penelitian ini, dapat juga diuraikan dengan penggunaan penelitian yang lain. Misalnya, penelitian tindakan kelas (PTK) yang menggunakan model kooperatif tipe STAD.Pelaksanaan pembelajaran model STADdapat juga digunakan dalam materi pembelajaran lainya seperti menulis teks hasil observasi, puisi rakyat, menulis pantun dan lain sebagainya. Dengan demikian, peneliti lain mendapat kesempatan untuk mengkaji penelitian mereka menggunakan model STAD lebih lanjut.

\section{PENUTUP}

- Pada bagianini, dipaparkan mengenai simpulan dan saran yang didasarkan atas rumusan masalah, hasil penelitian, dan pembahasan yang telah diuraikan pada uraian sebelumnya. Simpulan dan saran tersebut adalah sebagai berikut.

Pelaksanaan pembelajaran menulis teks fabel menggunakan Model Kooperatif tipe STAD yang dilakukan oleh guru Bahasa Indonesia di kelas VII A dan B SMP Negeri 2 Seririt telah disusun dan dilaksanakan sesuai dengan langkahlangkah model pembelajaran kooperatif $S T A D$ yang dimulai dari menyampaikan salam dan mengecek kehadiran siswa kemudian kegiatan inti yakni guru membentuk kelompok diskusi dengan masing-masing kelompok terdiri dari4-6 siswa, dan kegiatan akhir adalah Mengevaluasi dan mengakhiri pembelajaran. Dalam pelaksanaan pembelajaran menulis teks fabel guru sudah menggunakan Model Kooperatif tipe STAD dengan baik. Guru sudah menerapkan langkah-langkah pelaksanaan model pembelajaran kooperatif STAD sebanyak enam belas langkah sesuai dengan penerapan model kooperatif STAD.

Hasil belajar siswa setelah menggunakan Model Kooperatif tipe STAD yang dilakukan di kelas VII A dan $B$ di SMPN 2 Seririt mendapatkan hasil yang memuaskan dengan nilai rata-rata 83,55 yang dikategorikan baik. Diketahui dari 60 siswa terdapat 9 siswa mendapatkan nilai sangat baik dengan persentase 15\% dan sebanyak 51 siswa mendapat nilai baik dengan persentase $85 \%$. Mendapatkan hasil yang baik tentunya tidak terlepas dari pelaksanaan pembelajaran yang menggunakan Model Kooperatif $S T A D$. Jadi dapat peneliti simpulkan bahwa hasil belajar siswa setelah menggunakan model kooperatif tipe STAD adalah mendapatkan hasil memuaskan yang dikategorikan baik.

Pembelajaran teks fabel menggunakan Model Kooperatif STADmendapatrespons sangat positif dari siswa. Skor rata-rata yang diperoleh dari 60 siswa yang memberikan respons adalah 33.05 (sangat positif). Skor ini diperoleh dari jumlah skor siswa dibagi jumlah siswa. Berikut ini adalah rincian data yang diketahui dari hasil angket yang diisi oleh 60 siswa. Diketahui bahwa 53 orang siswa dengan persentase $88.3 \%$ memiliki respons sangat positif, kemudian 7 siswa dengan persentase $11.7 \%$ memiliki respons positif. Daridatatersebut,dapatdisimpulkanb ahwa pelaksanaan pembelajaran menulis teks fabel menggunakan Model Kooperatif STAD sangat cocok digunakan di SMP Negeri 2 Seririt membuat siswa lebih semangat dan termotivasi untuk belajar.

Adapun saran dari berbagai pihak antara lain: 
Bagi guru, Karena sudah terbukti bahwa model kooperatif tipe STAD baik dalam penggunaannya. Hendaknya perlu mempertahankan dan menerapkan dengan kualitasnya ditingkatkan agar mendapat hasil yang dicapai lebih maksimal dan memuaskan. Tidak hanya guru bahasa Indonesia tetapi guru lain juga bisa memanfaatkan model kooperatif STAD ini dalam mata pelajaran lain seperti IPA,IPS,Matematika dan lain sebagainya.

Bagi sekolah perlu adanya hubungan yang baik antara peneliti dan pihak sekolah selama proses pelaksanaan penelitian. Selain itu, sekolah juga diharapkan mencoba mengembangkan model STAD untuk masing-masing mata pelajaran sebagai upaya pengembangan sekolah, utamanya untuk peningkatan kualitas proses pembelajaran di sekolah. Bagisiswa SMPNegeri2 Seriritdiharapkan mampu berperan aktif dalam kegiatan pembelajaran. Dengan terlibat aktif dalam pembelajaran tentu akan meningkatkan hasil belajar siswa, sehinggadapatmeraihprestasibelajary ang lebihbaiklagidikelas-kelas selanjutnya. Sehingga siswa menguasai materi pelajaran dengan baik.

$\begin{array}{llr} & \text { Penelitian ini } & \text { mengkaji } \\ \text { sebatas pelaksanaan } & \text { model } \\ \text { kooperatif tipe STAD dalam } \\ \text { pembelajaran menulis fabel. }\end{array}$ Pembelajaran model kooperatif STAD juga dapat diterapkan dalam penggunaan penelitian lain seperti PTK atau pada pembelajaran materi lain yaitu teks laporan hasil observasi, menulis puisi, pantun, cerita rakyat dan lain sebaginya. Ini adalah peluang bagi peneliti lain untuk meneruskannya.

\section{DAFTAR PUSTAKA}

Angelia, F. P.2015. "Peningkatan Kemampuan Penalaran Logis Matematika Siswa Melalui Pembelajaran Discovery Methods Di Kelas X Sma Negeri 2 Sigli". Jurnal Peluang,(hlm. 24-30).

Badarudin. 2016. "Peningkatan Keterampilan Menulis

Karangan Narasi Melalui Metode Tanya Jawab Dengan Menggunakan Media Gambar Seri Di Kelas Iv Mi Ma'arif Nu Lamuk Purbalingga",Semantik, (hlm.90-93).

Fang, Liaw Yock. 2011. Sejarah Kesusastraan Melayu Klasik. Jakarta: Yayasan Pustaka Obor Indonesia.

- Harahap, N. 2013. Penerapan Model Pembelajaran

Kooperatif Tipe STAD

Terhadap Hasil Belajar Kognitif, Motivasi, Dan Aktivitas Belajar Siswa Pada Konsep Belajar Kognitif. Banda Aceh. (hlm.58-62).

Johnson.2000."https://media.neliti.co $\mathrm{m} / \mathrm{media} /$ publications/111149ID-pengaruh-pembelajarankooperatif-model-s.pdf.

Kurniasih,I dan Sani. 2015. Model Pembelajran.

Pena_Katapena.Penerbit@G mail.C̄om.

Kumarawati, K. 2015. "Penerapan Metode Pembelajaran Kooperatif Tipe StudentTeam Achievement Division (STAD) Untuk Meningkatkan KemampuanMenulis Teks Laporan Hasilobservasi Siswa Kelas X Mia 1 Sman 1 mendoyo" . E-jurnal pendidikan Ganesha hlm(3-9)

Lamba, H. A. 2006 . "Pengaruh Pembelajaran Kooperatif 
$\begin{array}{lcc}\text { Model } & \text { STAD Dan } & \text { Gaya } \\ \text { Kognitif } & \text { Terhadap } & \text { Hasil } \\ \text { Belajar } & \text { Fisika } & \text { Siswa }\end{array}$ Sma".Jurnal IImu Pendidikan, (hlm.122-123).

Muharom, T. 2014. "Pengaruh Pembelajaran Dengan Model KooperatifTipe Student Teams Achievement Division (STAD) Terhadap Kemampuan Penalaran Dan Komunikasi Matematik Peserta Didik Di Smk Negeri Manonjaya Kabupaten Tasikmalaya". Jurnal Pendidikan Dan Keguruan,(hlm.2-4.)

Ningsih, A. Y. 2018. "Implementasi Model Pembelajaran Kooperatif Tipe STAD Dalam Mata Kuliah Statistik Dasar Pada Program Studi Pendidikan Biologi".Jurnal Pendidikan Matetamtika Dan Ipa, (hlm. 31-37).

Nasution, Y. A. 2018. "Peningkatan Menulis Teks Fabel Melalui Model Pembelajaran Media Gambar". Jurnal IImiah Pendidikan Bahasa Dan Sastra Indonesia,(hlm.19-28).

Rahmawati,2016. "Pengembangan Media Pembelajaran Menulis Teks Fabel Dengan Macromedia Flash Bagi Siswa Smp ". Jurnal Pendidikan: Teori, Penelitian, Dan Pengembangan Volume: 1 Nomor: 7 Bulan Juli Tahun 2016.

Slavin, R. E. 2015. "Cooperative Learning (Teori, Riset Dan Praktik" tersedia pada https://Shopee.Co.Id/Coopera tive-Learning-\%28teori-RisetDan-Praktik\%29-OriginalRobert-E.-SlavinI.20591501.758289113 (diakses 12 januari 2019)
Sugiyono. 2008. Metode Penelitian Pendidikan:(Pendekatan Kuantitatif, Kualitatif Dan $R$ \& D) Alfabeta.

Wendra, I Wayan.2016. Penulisan Karya Ilmiah. Singaraja: Universitas Pendidikan Ganesha.

Zeya.2012. "FromMyBlog" tersedia pada

http://Belajarbarengziya.Blogs pot.Com/2012/04/Normal-0False-False-False-In-X-NoneAr.Html (11 januari 2019) 